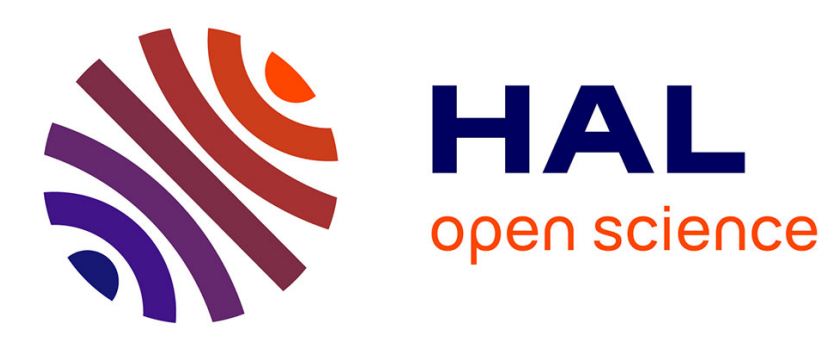

\title{
Returning to Dakar: A Mixed Methods Analysis of the Role of Migration Experience for Occupational Status
}

Cora Leonie Mezger Kveder, Marie-Laurence Flahaux

\section{To cite this version:}

Cora Leonie Mezger Kveder, Marie-Laurence Flahaux. Returning to Dakar: A Mixed Methods Analysis of the Role of Migration Experience for Occupational Status. World Development, 2013, 45, pp.223 - 238. 10.1016/j.worlddev.2012.11.009 . hal-01872656

\section{HAL Id: hal-01872656 https://hal.science/hal-01872656}

Submitted on 21 Apr 2021

HAL is a multi-disciplinary open access archive for the deposit and dissemination of scientific research documents, whether they are published or not. The documents may come from teaching and research institutions in France or abroad, or from public or private research centers.
L'archive ouverte pluridisciplinaire HAL, est destinée au dépôt et à la diffusion de documents scientifiques de niveau recherche, publiés ou non, émanant des établissements d'enseignement et de recherche français ou étrangers, des laboratoires publics ou privés. 
Returning to Dakar:

A Mixed Methods Analysis of the Role of Migration Experience for Occupational Status

\author{
Cora Mezker Kveder
}

Marie-Laurence Flahaux

MEZGER KVEDER C., FLAHAUX M.-L. (2013). "Returning to Dakar: A Mixed Methods Analysis of the Role of Migration Experience for Occupational Status", World Development, 45, 223-238.

\begin{abstract}
:
This paper applies mixed methods to contrast the professional situation of Senegalese return migrants and non-migrants in Dakar, and to explore the heterogeneity among return migrants due to differential migration experiences. Quantitative data from the MAFE-Senegal survey (2008) and qualitative semistructured interviews with return migrants are used. The results suggest that returnees are able to join the labor market after their return. While overrepresented in self-employed jobs, self-employment is not necessarily associated with positive migratory experiences. Rather than a choice, self-employment appears as a "last resort" for individuals who were not able to accumulate capital or prepare their return.
\end{abstract}




\section{INTRODUCTION AND RESEARCH OBJECTIVES}

The role of return migration and circular migration for development has been of increasing interest to policy makers in both origin and destination countries. Return migrants may have acquired new knowhow, skills and ideas, financial capital and social contacts during their stay abroad, all of which could be helpful in setting up a business, finding a job and bringing the new resources to use. However, migration may also have disruptive effects on the labor market reintegration. The financial resources may be insufficient to start a business activity, social ties at the origin may be weakened, and, if the employment taken up during migration is below a migrant's qualification, little or no human capital may have been acquired. Moreover, depending on the migration and return motives as well as the economic and social context in which the return takes place, returnees may also not participate in the labor market, may retire or decide to depart again for another stay abroad. A considerable amount of empirical research has investigated the occupational status of returnees, in particular with regard to their involvement in business activities, for countries and regions such as Egypt (McCormick and Wahba, 2001; Wahba and Zenou, 2009), Albania (Kilic et al., 2007; Piracha and Vadean, 2010), Moldova (Borodak and Piracha, 2011), Pakistan (Ilahi, 1999), the Maghreb (Mesnard, 2004; Tani and Mahuteau, 2008; Gubert and Nordman, 2011) and Mexico (Lindstrom, 1996). However, little evidence exists on return migration and returnees' labor market reinsertion in the context of Sub-Saharan Africa. Moreover, most authors have focused on the role of return migrants in promoting business activities, but analyzing wage-employment and the fact of being out of the labor force may provide insights into alternative strategies of return migrants. The objective of this paper is thus to contribute evidence on the labor market conditions of Senegalese return migrants in the region of Dakar, the capital city.

Senegal has a long, dynamic migration history and migration plays an important role in Senegalese society. Early Senegalese migration targeted mainly neighboring countries as well as the colonial power France (Guilmoto, 1998; Traore, 1994). However, in the context of the 1973 oil shock, France stopped its active recruitment policy. Migration to the traditional African destination countries was also hampered by increasing political instability (Robin et al., 1999). At the same time, a period of economic crisis and increasing poverty started in Senegal, following several droughts and a decline in the groundnut sector in the 1970s and the implementation of structural adjustment programs in the 1980s (Tall, 2002). As traditional destinations were less accessible, migration destinations diversified. Migration became increasingly directed towards countries outside of West and Central Africa as well as countries without any colonial or linguistic links, in particular Italy, Spain and the United States (Ndione and Broekhuis, 2006). Nowadays, over 630,000 Senegalese live abroad (4.9\% of the population; "Bilateral Migration matrix 2010", World Bank). Dakar, on which this analysis focuses, is the major departure and return region (2002 census), destination for internal migrants (ANSD, 2009) and represents the favorite target for migrant investments (Tall, 2009). Senegalese migration is rather diverse in terms of destination countries, education levels or migration motives. Concerning the region of Dakar, the 2002 census reveals that a large share of migrants left the country for economic reasons (68\%), but also to study $(18 \%)$ or for a family motive $(10 \%)$. The profile of Senegalese return migrants is similarly diversified, which can have an impact on the occupational status after return, with some more likely to be wage-employed (skilled or not) or self-employed, whereas others are rather expected to stay out of the labor market. Returns to the home country are not an exception in the Senegalese context, as every second migrant returns within 10 years (Flahaux et al., 2010). In European destination countries and, to a lesser extent in Senegal, return migration is met by an increasing policy interest in the potential role of Senegalese return migrants in promoting development. Several European destination countries introduced programs which aim to provide financial support for the start of economic activities. However, the success has been limited, as only few returnees have benefited from such measures and reintegration measures focused on self-employment and neglected access to salaried employment (Diatta and Mbow, 1999; Flahaux and Kabbanji, 2010).

The specific research objectives of this paper are twofold. Firstly, we aim to assess to what extent the fact of being a return migrant is related to occupational outcomes in the context of the Dakar labor market. The region of Dakar is characterized by persistent unemployment and underemployment (Ministère de 1'Economie et des Finances, 2004b), and job creation is concentrated in the informal sector, predominantly in low-productivity activities (World Bank, 2007). The trend towards further 
informalisation is also reflected in the figures on the distribution of workers across sectors. While in $2001 / 2002$ the informal sector provided work for $77 \%$ of the working population (1-2-3 survey, DPS, 2004), its share went up to $83 \%$ in 2008 (EDMC, ANSD, 2010). Within the informal sector, selfemployment represents around half of all employment. Moreover, businesses in the informal sector are very small. Only one out of five informal sector jobs are in businesses with six to 20 employees, the rest is constituted by workers in microenterprises and self-employment (1-2-3 survey, DPS 2004). The large majority in the informal labor market works at very low levels of income (at a median value of 34,000FCFA (52€) per month, World Bank, 2007) mirroring low productivity and education levels. However, some individuals in the informal market reach income levels that are equivalent to or even higher than those in the public sector. For this group, participation in the informal sector may be opportunity-driven rather than survivalist, as they may face lower bureaucratic hurdles and tax burdens than in the formal sector (World Bank, 2007). In addition, highly qualified jobs are rare, particularly because the public sector employment share has decreased steadily since the beginning of the 1980s (Ministère de l'Economie et des Finances, 2004a). It employs now only seven percent of the working population (EDMC, ANSD, 2010).

The second objective is to explore in how far differential migration experience is reflected in heterogeneous occupational attainment outcomes. What is the role of capital accumulated during the stay abroad, and does the context of return matter, in particular the return motive? Quantitative analyses using new biographic survey data on African migration (Migration between AFrica and Europe, MAFE $)^{1}$ explore whether returnees' labor market behavior differs from that of non-migrants at the time of the survey, and introduce selected migration and return characteristics. The latter question will be further investigated through complementary qualitative analysis based on interviews with return migrants in the region of Dakar. The interviews capture in a more comprehensive way how returnees experienced their stay abroad, the return and the time they have spent back in Dakar.

\section{A BRIEF REVIEW OF THE LITERATURE ON RETURNEES' PROFESSIONAL REINTEGRATION}

\section{(a) Theoretical framework}

Theoretical predictions regarding the process of labor market reintegration and the occupational attainment after return have been advanced by various bodies of migration theory. ${ }^{2}$

In static neoclassical migration models, the migration decision is based on a cost-benefit analysis by the potential migrant (Sjaastad, 1962; Harris and Todaro, 1970). Under the assumption of sustained wage differentials, migration is considered to be a permanent event. Return migration can be explained by a failed migration project. It is likely that the returnee faces difficulties in the context of a "failed" migration. No financial, human or social capital is accumulated abroad, and the migration episode interrupts the work experience in the home country. One can expect that returnees remain, at least temporarily, out of the labor market. They may also take up work with low entry-level barriers, representing a "last resort" option. Another explanation of return is that human capital accumulated in the host country is transferable and achieves higher relative returns at home than at the destination. Foreign education obtained abroad, for example, could situate the migrant at the middle of the host country distribution, but among the educational elite in the origin country (Dustmann, 2000). In this case, we would expect a smooth reintegration after return, in particular into skilled positions.

According to the New Economics of Labor Migration (NELM) literature, migration which takes place in a context of credit market imperfections in the origin country may serve to accumulate sufficient savings for investment at home. Having achieved the "target-level" of savings, migrants return to their home countries (Stark, 1991; Mesnard, 2004; Yang, 2006). If savings are accumulated with the expectation of starting a business activity, one should observe an over-representation of returnees among the self-employed and entrepreneurs. A further reason for return migration is a higher purchasing power of the host country currency in the home country (Stark et al., 1997). Under such conditions, one would expect to observe retirement return migration, whereby the migrant returns after the end of the 
working life in order to spend savings in the country of origin. In both cases, migration duration and activity after return may be decided simultaneously - target savers stay only as long as needed to accumulate the resources, while retirement returnees remain until the end of their working life abroad (Dustmann and Kirchkamp, 2002).

The structural approach views the process of reintegration after return in a rather pessimistic light (Gmelch, 1980; Colton, 1993): returnees may not be able to reintegrate if the "gulf" between norms and values at origin and their own is too large and decide to depart again. Alternatively, they may also respond to pressure from their origin household and spent their savings on consumption rather than productively. The structuralist approach to return migration suggests that returnees are in the short term rather inactive and that they take up less productive activities when participating in the labor market. Moreover, the sample of return migrants observed at origin may be self-selected if "frustrated" returnees decide to re-migrate.

Social ties between origin and destination during the migration period and after return are at the heart of both transnationalist theory and social network theory (Cassarino, 2004). Migrants maintain regular contact with the origin community, for example through visits and transfers. These links allow for a better preparation of the return and a smooth reintegration after return. Transnationalists focus on networks defined on the basis of kinship and common origin, while the social network theory emphasizes "built" relationships such as associations in the host country, groups with common aims and whose members include migrants as well as non-migrants. The existence of links to socio-economic networks abroad after return may facilitate "cross-border" activities, such as import-export businesses, but also skilled employment in international companies or institutions.

Finally, Cassarino $(2004,2008)$ emphasizes willingness to return and preparation of the return as elements which determine the success of the reintegration after return. Combining elements of the previous theories, he highlights that returnees are better or worse prepared for the time after return depending on their capacity to acquire social, financial and human resources, both before and during migration. If the return is decided by others or by external circumstances, such as the death of a family member or worsened political conditions in the host country, the returnee may have insufficient information about opportunities and may not have accumulated sufficient resources for a successful reinsertion at home. Returnees who have been able to mobilize various types of resources and who decide themselves whether and when to return, should therefore encounter less problems.

\section{(b) Empirical evidence on return and professional reintegration from the literature}

There is a sizeable empirical work on the occupational status of return migrants. ${ }^{3}$ However, most studies do not compare return migrants with non-migrants, or are examining country contexts which are very different from the Sub-Saharan African case in general, and from the Senegalese in particular. This summary concentrates therefore mostly to studies on return to African countries.

Both descriptive and multivariate analyses including non-migrant as well as return migrant samples suggest that the proportion of entrepreneurs is higher among return migrants than non-migrants, and point towards the role of capital mobilization (e.g. McCormick and Wahba, 2001 and Wahba and Zenou, 2009 on Egypt; Mesnard, 2004 on Tunisia). For example, Wahba and Zenou (2009), who define Egyptian entrepreneurs as individuals who are employers or own a non-farm economic unit, find that returnees are more likely to become entrepreneurs than non-migrants. According to the authors, this finding suggests that the migration experience compensates for the loss of social networks during migration. Studies in the African context have so far been limited to the study of entrepreneurship, without distinguishing wage-employment statuses or inactivity as alternatives. However, for Albania, Piracha and Vadean (2010) find that return migrants are less likely to be wage-employed and more likely to be out of the labor market. The distinction between own-account workers and entrepreneurs indicates that returnees overrepresented in the latter group, but not in the former.

Several papers restrict their analysis to return migrants to examine in more detail the role of migration experience, focusing on determinants of business investments (e.g. Black and Castaldo (2009); Mesnard (2004); Gubert and Nordman, 2011). For the African countries studied, the findings match the 
theoretical predictions regarding the role of capital mobilization. Financial capital accumulated during migration and remitted or transferred back at the end of the migration period appears to be a particularly strong predictor of entrepreneurship after return. However, also human capital in the form of work experience acquired has a positive effect. Formal education acquired abroad does not seem to matter for self-employment, but raises the probability of wage employment and reduces the probability of unemployment, according to findings by Tani and Mahuteau (2008) on returnees to the Maghreb countries. In a study based on the 1-2-3 survey conducted in 2001 and 2002 in seven major cities in the West African Economic and Monetary Union (WAEMU), including Dakar, De Vreyer et al. (2010) show that destination region matters as only individuals who returned from an OECD country are more likely to be an entrepreneur. The authors suggest as possible explanation the better opportunities for capital accumulation or for acquisition of "specific knowledge" valued in the sectors they are targeting. Independently of the migration destination, returnees appear to be less likely to be in public wageemployment than non-migrants. Previous studies' results with regard to the effect of migration duration, a proxy for capital accumulation, are more conflicting. While McCormick and Wahba (2001) find a positive effect of duration on returnees' entrepreneurship in Egypt, and Black and Castaldo (2009) similarly for returnees in Ghana and Cote d'Ivoire, migration duration has no effect in the findings of Gubert and Nordman (2011) on returnees in Algeria and Morocco.

With regard to factors facilitating or constraining the preparation of the return, Gubert and Nordman (2011) find that if the return was "forced" (no documents or deportation) entrepreneurship after return becomes less likely. Moreover, the positive effect of transfers may also reflect their role in maintaining links to the origin country which are essential for preparing the return. Similarly, Black and Castaldo (2009) find that social capital kept and maintained through short visits and membership in migrant associations increases the chances of becoming entrepreneur.

Qualitative studies focus on the subjective experience of the life after the return. Davids \& van Houte (2008) argue that a qualitative perspective is indispensable in studies aiming to understand the "embeddedness" of return migrants, as they did in the case of their study about migrants (from Angola and Guinea) returned from the Netherlands. They highlight that a better anticipated and prepared return leads to improved "embeddedness" back in the home country. Besides, qualitative analyses from life stories help to grasp the motivation of the elite among returnees to Ghana and Cote d'Ivoire who wish to apply know-how acquired abroad when starting a business, but also to give the floor to returnees who face difficulties trying to find employment (Ammassari, 2005). Carling (2004) studies the reintegration experience of returnees in Cape Verde. He emphasizes that the wage-employed tend to feel frustrated. Rigid hierarchies prevent them from progressing in their career and they end up being supervised by people who are less qualified than them. A qualitative study on Malian return migrants highlights that those who lived in precarious conditions in France could not conceive a sustainable return project, even if they had benefited from financial assistance (Linares, 2009). Chappart (2008), who collected stories of deported Cameroonians, shows how these returnees are marginalized, struggle to reintegrate into society and want to leave again. Sinatti (2011) concluded in her qualitative study of Senegalese returnees that migrants' self-perception of a successful return is still largely associated with permanent return.

\section{(c) Research hypotheses}

The theoretical and empirical literature suggests hypotheses with regard to the relationship between return migration and occupational status. The common hypothesis in the empirical literature is that return migrants are overrepresented among entrepreneurs. However, this association is likely to vary depending on the characteristics of the return and the migration experience.

\section{(i) Willingness and links to origin}

The return motive variable reflects the concept of "willingness to return" proposed by Cassarino (2004). Individuals who take the return decision themselves are likely to be better prepared for their return and the life back in Senegal than those who did not, because another person decided for them, because return was triggered by external events or because return was due to a "failed" migration experience as proposed by the neoclassical literature. Our hypothesis is that individuals who decide themselves if and when to return are more likely to find a job, in general, and a job of higher skill-content in particular, 
than non-migrants. The relationship with self-employment status is ambiguous. If entrepreneurship refers to sustainable and higher-level business activities, the fact that the return was involuntary is expected to be negatively correlated with self-employment status. If self-employment occurs mainly in the informal sector, which has at least a subsector with relatively low entry barriers, it may constitute the second-best option when (skilled) wage employment is not accessible. In this case, we would rather expect that ill-prepared returnees become self-employed. The ambiguity in the correlation with selfemployment is also present for other variables reflecting the preparedness of the returnee and the degree of capital accumulation at the time of return.

The fact of having sent remittances during the stay abroad can be interpreted in several ways. Transfers can reflect that migrants maintain links with the family members at origin, what would help them gather information about labor market conditions and facilitate their reintegration after their return (transnationalist/social network theory). While being rather active in the labor market, one cannot provide a concrete hypothesis on the type of activity. Moreover, target savers could aim to accumulate part of the capital at origin, in particular in light of an investment in business activities (New Economics of Labor Migration). However, transfers may also reflect the dependency of the origin household on the migrant's support, a hypothesis which is supported by qualitative analyses (Linares, 2009). In this case, the returnee is forced to quickly find a replacement for remittance transfers, once back in the home country. If self-employment work presents the lowest entry barriers, the return migrant is likely to become self-employed, rather than to spend time on searching a salaried job.

\section{(ii) Conditions for capital accumulation abroad}

A third interpretation of the role of remittances would imply that target savers accumulate part of the capital at origin (New Economics of Labor Migration). In this case we should also observe more involvement in self-employment, but in activities demanding higher starting capital. However, given that money is fungible and the control of the capital is in the hands of the household, it is rather unlikely that savings are accumulated and re-transferred to the migrant after the return.

The process of capital accumulation beyond financial capital is further captured by measures of migration duration ${ }^{4}$, brain waste, the acquisition of education while abroad, and the fact of having gained work experience during the migration. The literature generally suggests that longer migrations should be positively associated with self-employment, as more capital and know-how may be accumulated. However, due to the fact that the category of self-employment is likely to include mainly low-level activities, we expect shorter rather than longer durations to be positively related to selfemployment. If returnees worked in the host country in activities below their level of qualification, skills and know-how may have not increased or even been lost over this period ("brain waste"). In this case we would expect migrants to experience difficulties in the reintegration process, in particular to be less likely to take up skilled jobs. Individuals who gained education abroad should have better opportunities in skilled wage-employment than non-migrants, under the assumption that the knowledge acquired abroad is transferrable to the Dakar labor market and that it is more highly valued than education acquired in Senegal. Foreign work experience should also increase the level of (work-related) human capital and know-how and help in finding a job after return. However, one cannot provide a prediction about the skill-level of the activity after return, which depends on the skill-level of the previous work experience. Individuals who were mainly inactive during migration may also be more likely to remain without income generating activity after return.

The period of departure and the destination region of the last migration may encompass institutional and network effects, but may also proxy for the opportunities and conditions for capital mobilization. Early migrations from Senegal were facing less legal and economic hurdles and are expected to coincide with larger opportunities for capital accumulation. ${ }^{5}$ This is the case for destinations in Africa before the structural adjustment programs were implemented in the 1980s and Europe before the enhancement of immigration restrictions in the same period. However, as both the access to education and the labor market abroad posed less barriers, early return migrants may have benefited in terms of reintegration into a skilled job or better business opportunities. Moreover, returnees from a destination in Africa should face fewer difficulties to reintegrate, in particular in self-employment occupations if this sector is characterized by relatively low entry-barriers. They come back from a context which is not very 
different from the Senegalese one, and may have kept closer ties to their family at home. At the same time, they may not have accumulated large amounts of capital. Returnees from Europe may first face more problems in readjusting to life in Senegal, but may also have acquired more capital which can facilitate the reinsertion in productive entrepreneurship or skilled jobs in the long-run.

\section{(iii) Context of the return experience}

Finally, we distinguish by the period of return to explore to some extent the context of the return experience, which was highlighted in particular by the structural literature. The economic and political conditions at origin at the time of return are likely to influence the occupational status of return migrants as compared to non-migrants, who did not interrupt their working life in Senegal. We expect to find higher probabilities of self-employment since the start of the structural adjustment program in the mid 1980 s, a period in which access to formal sector jobs became increasingly difficult. Despite a more positive overall economic situation in recent years (in terms of GDP growth), unemployment and underemployment have rather been on the increase, in particular in the urban labor market of Dakar. Self-employment and inactivity may therefore be the dominant types of occupation for returnees who came back after 1997.

\section{DATA AND METHODS}

This work combines quantitative and qualitative methods to study the occupational reinsertion of return migrants. Quantitative methods allow for a numerical assessment of the occupational status of return migrants and non-migrants in the Dakar region. Qualitative methods, on the contrary, can supply more detailed information about the context in which return and reinsertion take place, as well as about the subjective assessment of the work situation, by covering questions which are not included in the quantitative survey questionnaire. The qualitative analyses, which concentrate on returnees only and describe the reintegration experience since return, are thus regarded as a complement to the quantitative results. Mixing the two methods can facilitate the mutual validation of findings and produce a more coherent and complete picture of the role of migration and migration experience for occupational reintegration. During spring 2009 and summer 2010, 46 qualitative interviews were carried out with return migrants living in the region of Dakar. Due to reasons of confidentiality, return migrants interviewed in the context of the quantitative survey (MAFE) could not be re-contacted. The sampling of respondents, which took mainly place in public spaces such as on public transport or in the street, intended to include returnees with diverse characteristics and migration experiences. Individual characteristics of interviewees as well as their occupational status are summarized in Table 1. The reference to formality or informality of the status is self-reported. Makhete (44 years), for instance, explains that formalizing his business activity entails risks he is not willing to take for the time being. "Then you have to pay taxes, that's normal, but I know many people who had to close down because of the taxes." 
Table 1: Sample of respondents of qualitative interviews

\begin{tabular}{|c|c|c|}
\hline Variables & Categories & $\begin{array}{l}\text { Number of } \\
\text { respondents }\end{array}$ \\
\hline \multirow[t]{2}{*}{ Gender } & Men & 34 \\
\hline & Women & 12 \\
\hline \multirow[t]{4}{*}{ Destination } & Africa & 21 \\
\hline & Europe & 16 \\
\hline & Africa and Europe & 7 \\
\hline & North America & 2 \\
\hline \multirow[t]{2}{*}{ Level of education } & Low & 22 \\
\hline & High & 24 \\
\hline \multirow[t]{4}{*}{ Migration motive } & Work & 26 \\
\hline & Studies & 6 \\
\hline & Studies and work & 6 \\
\hline & Follow a family member abroad & 8 \\
\hline \multirow[t]{6}{*}{ Occupational status } & Unemployed and housewives & 8 \\
\hline & Students and trainees & 2 \\
\hline & Skilled wage-employed & 6 \\
\hline & Unskilled wage-employed & 3 \\
\hline & $\begin{array}{l}\text { Employers and self-employed (formal labor } \\
\text { market) }\end{array}$ & 10 \\
\hline & $\begin{array}{l}\text { Employers and self-employed (informal } \\
\text { labor market) }\end{array}$ & 17 \\
\hline Total $n=$ & & 46 \\
\hline
\end{tabular}

The interviews were semi-structured, following a comprehensive interviewing guide in order to streamline the reporting and recording of the narratives. The emphasis was placed on the migratory experience of the interviewees, on the resources they had acquired abroad (social capital, human capital and financial capital), and on the process of professional reinsertion after their return in Senegal. ${ }^{6}$

The quantitative analyses performed in this paper use recent biographic survey data collected in the Dakar region in the framework of the MAFE-Senegal project (Migration between Africa and Europe). The region with its four administrative departments Dakar, Pikine, Guédiawaye and Rufisque accounts for approximately one quarter of the national population. In a first step, National Census data from 2002 was used as a sampling frame to group census districts into 10 strata of equal size based on the migration prevalence. Six districts were randomly drawn out of each stratum and a micro-census was conducted in the sampled districts to update the list of households. Stratified into non-migrant and migrant households, 1320 households were sampled as secondary units. Household surveys were conducted in early 2008, and individuals within households were sampled for the subsequent biographic interviews. The eligibility criteria for the individual questionnaire established that individuals had to be between 25 and 75 years of age, born in Senegal and of present or past Senegalese nationality. Interviews were conducted with 1063 individuals, out of which 870 are non-migrants and 193 are return migrants, defined as individuals who had spent at least one year abroad and were at the time of the survey members of the household. The sample is representative of the Dakar region, and inference to the population characteristics is thus only valid at the regional and not at the national level. ${ }^{7}$ The sampling design is taken into account in both descriptive and multivariate analyses by using the Stata survey commands.

The individual questionnaire recorded retrospective information at annual intervals about the respondent's life. Data hence cover the time from birth till the survey date, for both non-migrants and return migrants. In addition to more common life histories such as housing, family formation and activity histories, the survey collected data on many migration-specific histories (e.g. migrations and return 
migrations lasting at least one year, migration of network members, short returns, remittances, residence and work permits).

The main quantitative variable of interest is the self-reported occupational status in 2008, distinguishing between skilled and unskilled wage-employed, self-employed and "no income earners". Due to the relatively low number of observations, certain types of occupations have been conflated. The "selfemployed" category also contains the few individuals who declared to be employers (17 persons), and the data do not permit to further differentiate this category in order to account for productivity, size, and formality of the activity. This is unfortunate, given the theoretical and empirical suggestions regarding the heterogeneity of self-employment activities in a developing country context. The self-employment category is thus likely to contain more heterogeneous types of activities and attract heterogeneous types of returnees. The description of activities reported by self-employed in the MAFE survey illustrate the breadth, diversity and quality of the type of work performed. While, for instance, a large number of individuals report activities in the trade sector, activities range from street vendors to shop owners and wholesale. Similarly, one finds tailors who work from home, and tailors with a workshop and sales shop, or electricians who work alone whereas others declare to have employees. Although constituting a smaller number, there also appear to be examples of highly educated self-employed, (e.g. an accountant, a translator, or a doctor). The "no income earner" category also conflates different types of individuals, as those who work as a family help (14 individuals) or apprentice/intern/in training (50) are grouped together with those who declare that they are retired (40), unemployed (49) or inactive (275) into a group of "no income earners". The group shares the trait of not performing regularly a remunerated labor market activity.

Other variables examined descriptively include two internationally standardized continuous occupational rankings, Ganzeboom et al.'s International Socioeconomic Index of Occupations (ISEI) and Treiman's Standard International Occupational Prestige Scale (SIOPS). An income variable refers to revenues from all types of sources, in the last month of the given employment episode. The absolute and relative deprivation variables are subjective well-being measures at household level.

The aim of the analysis is to provide descriptive evidence of the relationship between return migrant status and occupational outcomes, rather than to report causal effects. In addition to cross-tabulations and mean tests, we estimate the association between return migrant status and occupational status at the time of the survey and controlling for a set of individual characteristics. The outcomes are estimated in the form of a multinomial logit model which is expressed as:

$$
\operatorname{Prob}\left[y_{i}=j\right]=\frac{\exp \left[\alpha_{j}+\beta_{j} X_{i}+\gamma_{j} R M_{i}\right]}{\sum_{k=0}^{4} \exp \left[\alpha_{j}+\beta_{k} X_{i}+\gamma_{k} R M_{i}\right]}, j=1,2,3,4
$$

where $y$ represents the $\mathrm{j}(=1,2,3,4)$ outcomes in which the individual may be attached to the labor market. The $\mathrm{j}=4$ category (no income earner) is used as base category. ${ }^{8}$ We repeat the estimation for each variable discussed in the hypotheses section above, changing the definition of the return migrant status $\mathrm{RM}_{\mathrm{i}}$, our variable of interest. The first estimation uses a simple indicator variable (non-migrant/return migrant), and dummies distinguishing return migrant subgroups are included in subsequent estimations in order to examine the role of migration and return experiences. For instance, we split the return migrants into those who had returned voluntarily and those who returned involuntarily. The reference category remains "to have no migration experience". In all estimations we control for the same set of individual and family-level characteristics $\left(\mathrm{X}_{\mathrm{i}}\right)$. These include sex; educational attainment; age; household head status; marital status; number of dependent children between zero and sixteen years; and a variable that measures occupational status at age 25 or before first departure in case departure took place before the age of 25. This definition ensures an identical measure for the two groups whenever possible, while ensuring that occupation is measured pre-migration. In controlling for previous occupational status, we follow several papers in the literature, such as Wahba and Zenou (2009) or Gubert and Nordman (2011). If individuals have throughout their lifetime a higher probability of attachment to a specific occupational category, for instance to self-employment, controlling for occupational status early in life may help to net out the role of migration experience. ${ }^{9}$ 
Several limitations of the quantitative approach and the choice of variables should be noted. In this approach, which is pooling migrants and non-migrants, we are not able to control for all relevant return characteristics at once, since sample size limits the possibility of introducing multiple interactions with the return status, which would also be difficult to interpret. We are also not able to estimate separate models for non-migrants and return migrants in a second step and include in this way all relevant migration and return characteristics. Similarly, sample size limitations prevent us from estimating models separately for men and women, or to test interactions of the return migrant status with other socio-demographic characteristics.

The analysis, providing descriptive rather than causal evidence, does not account for possible biases due to endogeneity of the return migrant variables. Migration behavior is usually characterized by selfselection, both in terms of observable and unobservable characteristics. If observable, but omitted variables, or if unobserved characteristics, such as motivation, ability or risk aversion, are correlated with the return migrant status as well as with the outcome variable, the estimated effect of return migrant status will be biased. Three types of selection processes are at work in the context of this analysis. Individuals first select into migration and then into return. Moreover, returnees who remain in Dakar may be self-selected if those who are unsuccessful in reintegrating back home leave again. However, previous studies have focused on the joint effect and have found either no evidence to support endogeneity of the return migrant status (e.g. Démurger and Xu, 2011; Borodak and Piracha, 2011; Piracha and Vadean, 2010; Barrett and O'Connell, 2001; Co et al., 2000 (men)), or results pointed towards a negative relationship between migration and occupation-related outcome variables, at least in terms of entrepreneurship and earnings (e.g. Wahba and Zenou, 2009; Kilic et al., 2007; Co et al., 2000 (women); De Vreyer et al., 2010). Overall, the literature suggests that estimates without correcting for endogeneity tend to be underestimated. There is less evidence on the direction of the bias with regard to different wage-employment statuses. ${ }^{10}$ Endogeneity of certain return migrant dummies accounting for migration characteristics can furthermore be caused by the fact that decisions with regard to migration/return and the envisaged occupation back in Senegal are taken simultaneously. This is potentially the case for variables distinguishing by migration duration, acquisition of education while abroad or the return motivation if a job is found before returning. These limitations have to be kept in mind in the subsequent discussion of results.

\section{RESULTS}

\section{(a) Descriptive statistics}

Before examining the occupational variables of interest, we briefly compare return migrants and nonmigrants with regard to key socio-demographic characteristics (Table 2). Return migrants in our sample are, on average, four years older than non-migrants, males are overrepresented and return migrants are more likely to be household heads. However, return migrants and non-migrants report a very similar profile in terms of educational attainment and family variables. This suggests that differences in education do not seem to be at the bottom of possible differences in occupational status variables and well-being indicators. Migration experience may indeed play a role on its own. Turning now to the occupational outcomes, one observes that return migrants are underrepresented among the group of non income earners (Table 2). This suggests that individuals with past migration experience are in general able to enter the labor market after their return to Dakar, and that they may benefit from capital accumulated abroad when searching for an occupation. The lower percentage of "no income earners" among return migrants could, however, also be related to the higher share of men and household heads. Also the distribution across occupational status categories suggests that labor market reinsertion is rather successful. While differences are not statistically significant, a larger share of returnees than of nonmigrants seem find a job in skilled wage-employment, while the latter are more involved in unskilled jobs. The largest differential, however, can be observed in the category of the self-employed. $45 \%$ of all return migrants start their own business activity, against $29 \%$ of non-migrants, a result in agreement with findings from other countries and regions. This relative ease of returnees to become self-employed may be due to the starting capital and know-how accumulated during the migration. An alternative 
interpretation is that self-employment after return represents an "easy entry" into the labor market for returnees who do not access salaried employment, but need to work to continue supporting their families.

Table 2: Descriptive statistics of occupational and well-being characteristics by return migrant status

All Non- Return Mean/

migrants migrants median test

non-migrant

vs. returnee

\begin{tabular}{|c|c|c|c|c|c|}
\hline \multicolumn{6}{|c|}{ INDIVIDUAL CHARACTERISTICS } \\
\hline Age & & 40.3 & 39.9 & 43.7 & $* *$ \\
\hline Female & & 0.54 & 0.57 & 0.36 & $* * *$ \\
\hline Eaucanon & No education & 0.30 & 0.31 & 0.23 & n.s. \\
\hline & Primary & 0.37 & 0.37 & 0.37 & n.s. \\
\hline & Secondary & 0.23 & 0.23 & 0.28 & n.s. \\
\hline & Tertiary + & 0.09 & 0.09 & 0.12 & n.s. \\
\hline Household head & & 0.19 & 0.17 & 0.32 & $* * *$ \\
\hline In partnership & & 0.67 & 0.67 & 0.72 & n.s. \\
\hline At least one child aged 0-16 years & & 0.59 & 0.58 & 0.60 & n.s. \\
\hline
\end{tabular}

$\begin{array}{rrrr}\text { At least one child aged 0-16 years } & 0.59 & 0.58 & 0.60 \\ \text { OCCUPATION AND WELFARE CHARACTERISTICS }\end{array}$

\begin{tabular}{|c|c|c|c|c|}
\hline \multicolumn{5}{|l|}{ Occupations and occupational scores } \\
\hline No income earner & 0.42 & 0.44 & 0.27 & $* * *$ \\
\hline Skilled wage-employed & 0.13 & 0.13 & 0.19 & n.s. \\
\hline Unskilled wage-employed & 0.14 & 0.14 & 0.09 & n.s. \\
\hline Self-employed/employer & 0.31 & 0.29 & 0.45 & $* * *$ \\
\hline ISEI score (all) - means & 37.5 & 36.8 & 42.2 & $* * *$ \\
\hline ISEI score skilled wage-employed & 44.2 & 43.1 & 50.5 & n.s. \\
\hline ISEI score unskilled wage-employed & 27.9 & 27.5 & 32.0 & n.s. \\
\hline ISEI score self-employed/employer & 38.7 & 38.1 & 41.1 & n.s. \\
\hline SIOPS score (all) - means & 34.6 & 33.8 & 39.4 & $* * *$ \\
\hline SIOPS score skilled wage-employed & 41.9 & 40.5 & 49.5 & $* *$ \\
\hline SIOPS score unskilled wage-employed & 26.7 & 26.4 & 30.3 & n.s. \\
\hline SIOPS score self-employed/employer & 34.4 & 33.7 & 37.4 & $*$ \\
\hline \multicolumn{5}{|l|}{ Sector of activity/qualification } \\
\hline Primary sector \& basic tasks & 0.09 & 0.09 & 0.04 & $*$ \\
\hline Service sector (excl. salesmen) & 0.20 & 0.21 & 0.12 & $*$ \\
\hline Salesmen & 0.33 & 0.32 & 0.41 & n.s. \\
\hline Craft/Industry & 0.22 & 0.21 & 0.30 & n.s. \\
\hline Higher-level jobs & 0.16 & 0.16 & 0.14 & n.s. \\
\hline \multicolumn{5}{|l|}{ Income } \\
\hline Average monthly income $(€)$, in 2008 & $180 €$ & $169 €$ & $338 €$ & $* * *$ \\
\hline Less than 3 years migration experience & - & - & $206 €$ & \\
\hline 3-7 years migration experience & - & - & $348 €$ & \\
\hline 8 and more years migration experience & - & - & $476 €$ & \\
\hline Median monthly income $(€)$, in 2008 & $106.7 €$ & $107 €$ & $152 €$ & $*$ \\
\hline \multicolumn{5}{|l|}{ Absolute subjective deprivation } \\
\hline $\begin{array}{l}\text { Barely sufficient or insufficient financial } \\
\text { resources to purchase basic goods }\end{array}$ & 0.41 & 0.42 & 0.30 & $* *$ \\
\hline Sufficient resources & 0.59 & 0.58 & 0.70 & $* *$ \\
\hline \multicolumn{5}{|l|}{ Relative subjective deprivation } \\
\hline Better relative living conditions & 0.19 & 0.18 & 0.24 & n.s. \\
\hline Similar living conditions & 0.65 & 0.66 & 0.57 & n.s. \\
\hline Worse living conditions & 0.16 & 0.16 & 0.19 & n.s. \\
\hline Sample size & 1063 & 870 & 193 & \\
\hline
\end{tabular}

Source: authors' elaboration based on MAFE-Senegal (2008)

Notes: The mean test column indicates the significance level of mean differences between return migrants and non-migrants.

The median test on median monthly income is a non-parametric K-sample test on the equality of medians.

Statistical significance: $* * *$ at $1 \% ; * *$ at $5 \%$; at $10 \%$; n.s. $=$ not significant 
We use the International Socioeconomic Index of Occupations (ISEI) and Standard International Occupational Prestige Scale (SIOPS) scores to obtain some insights into the socio-economic status and prestige of jobs and business activities performed by non-migrants and returnees. Overall, return migrants appear to perform occupations of higher socio-economic status and prestige. Once one distinguishes by occupational status, it appears that the main gain from migration experience relates to accessing more prestigious skilled salaried but also self-employed jobs. Independently of the migration status, the scores also provide information regarding the ranking of self-employed versus wageemployment in the labor market context of Dakar. Self-employed activities are, at the average, ranked higher than unskilled jobs, but lower than skilled jobs. Further insights regarding the type of work are gained from the information provided on tasks and duties carried out on the job. Returnees seem to prefer activities as traders and craftsmen, sectors which are most characterized by self-employment, though the differences are not statistically significant. A relatively larger proportion of non-migrants works in other service occupations and carries out basic manual tasks. There does not seem to be a large difference with regard to "higher-level" jobs, which group the occupational groups of clerks, professionals and executives.

The success of the reintegration should also be reflected in wealth and well-being indicators. According to a measure of total monthly income at the time of the survey, return migrants are at the average considerably better off than non-migrants. However, one can observe that the migration duration matters. Returnees with longer migration durations reap considerably higher incomes than returnees who stayed abroad for a short period, and one does not observe a disadvantage of individuals who stayed abroad for a relatively long duration. Yet, even returnees who spent a relatively short time abroad still achieve a higher average total income than individuals without any migration experience.

The subjective measure of absolute well-being provides a similar picture. Return migrants report less often than non-migrants that their households possess insufficient or barely sufficient financial resources to provide for basic goods. Interestingly, returnees do not perceive the living conditions of their household as superior to the situation of other households they compare themselves with. While the share reporting better living conditions is slightly higher in the return migrant group, the same is the case for those reporting worse conditions, and the differences between return migrants and non-migrants are not statistically significant. One possible explanation is that the reference group of returnees is different from that of non-migrants (higher up in the wealth distribution). Moreover, qualitative research on returnees in Dakar suggests that returnees need to present themselves as particularly "modest" in order to be reaccepted in their community (Flahaux, 2009).

The results from the basic descriptive statistics are in line with evidence from other country contexts, and suggest that there is a positive association between being a return migrant in the region of Dakar and access to work. The migration experience does not seem to represent a disruptive factor. Moreover, returnees appear to be more likely to work in self-employment than non-migrants. However, the descriptive analysis does not control for other personal characteristics, such as sex, age and education, which affect occupational status and are also likely to be correlated with the return migrant status. Moreover, since all returnees are grouped together, the results do not account for any differences in their respective migration and return experiences. We will therefore turn to the discussion of findings from several multivariate models, in which we vary the nature and definition of the return migrant variable, and discuss those findings in the light of the qualitative analysis.

\section{(b) Results from the occupational status models}

\section{(i) Control variables}

All models include the same set of control variables (sex, education, age, household head status, marital status, occupational status at age 25 for non-migrants/before first departure before returnees and the number of children under age 16). Table 3 presents the results in terms of probability point changes in the respective occupational outcome based on discrete change from the base level for categorical variables and average marginal effects for the number of children, the only continuous control variable. ${ }^{11}$ 
Table 3: Multinomial logit estimates of occupational status in 2008 (with return migrant dummy; average marginal effects)

\begin{tabular}{|c|c|c|c|c|c|}
\hline Variable & Category & $\begin{array}{l}\text { Skilled wage } \\
\text { employed }\end{array}$ & $\begin{array}{l}\text { Low-skilled } \\
\text { wage } \\
\text { employed }\end{array}$ & Self-employed & $\begin{array}{l}\text { No income } \\
\text { earner }\end{array}$ \\
\hline \multirow[t]{7}{*}{ Age } & Below 30 & (ref) & (ref) & (ref) & (ref) \\
\hline & 31 to 40 & 0.007 & 0.044 & 0.076 & -0.127 \\
\hline & & [0.031] & {$[0.028]$} & {$[0.042]^{*}$} & {$[0.046]^{* * *}$} \\
\hline & 41 to 55 & 0.042 & 0.008 & 0.119 & -0.168 \\
\hline & & {$[0.040]$} & {$[0.028]$} & {$[0.047]^{* *}$} & {$[0.050]^{* * *}$} \\
\hline & 56 or older & -0.097 & -0.056 & 0.043 & 0.111 \\
\hline & & {$[0.026]^{* * *}$} & [0.041] & {$[0.060]$} & {$[0.073]^{*}$} \\
\hline \multirow[t]{3}{*}{ Sex } & Male & (ref) & (ref) & (ref) & (ref) \\
\hline & Female & -0.107 & -0.044 & -0.037 & 0.188 \\
\hline & & {$[0.030]^{* * *}$} & [0.029] & [0.040] & {$[0.044]^{* * *}$} \\
\hline \multirow[t]{7}{*}{ Education } & No education & (ref) & (ref) & (ref) & (ref) \\
\hline & Primary & -0.008 & 0.041 & -0.059 & 0.026 \\
\hline & & [0.032] & [0.031] & [0.047] & {$[0.050]$} \\
\hline & Secondary & 0.044 & -0.001 & -0.121 & 0.078 \\
\hline & & [0.038] & {$[0.034]$} & {$[0.047]^{* *}$} & [0.050] \\
\hline & Tertiary+ & 0.231 & -0.099 & -0.150 & 0.018 \\
\hline & & {$[0.064]^{* * *}$} & {$[0.032]^{* * *}$} & {$[0.082]^{*}$} & [0.073] \\
\hline \multirow{7}{*}{$\begin{array}{l}\text { Early professional } \\
\text { experience }\end{array}$} & Skilled wage employed & (ref) & (ref) & (ref) & (ref) \\
\hline & Unskilled wage employed & -0.423 & 0.513 & -0.036 & -0.054 \\
\hline & & {$[0.078]^{* * *}$} & {$[0.062]^{* * *}$} & {$[0.066]$} & {$[0.088]$} \\
\hline & Self-employed & -0.454 & 0.027 & 0.614 & -0.187 \\
\hline & & {$[0.073]^{* * *}$} & {$[0.026]$} & {$[0.064]^{* * *}$} & {$[0.071]^{* *}$} \\
\hline & No income earner & -0.442 & 0.041 & 0.063 & 0.338 \\
\hline & & {$[0.072]^{* * *}$} & {$[0.023]^{*}$} & {$[0.057]$} & {$[0.072]^{* * *}$} \\
\hline \multirow[t]{3}{*}{ Status in $\mathrm{HH}$} & Not HH head & (ref) & (ref) & (ref) & $(r e f)$ \\
\hline & Household head & 0.011 & 0.013 & 0.005 & -0.029 \\
\hline & & [0.031] & [0.032] & {$[0.047]$} & [0.049] \\
\hline \multirow[t]{3}{*}{ Marital status } & Single & (ref) & (ref) & (ref) & (ref) \\
\hline & In partnership & -0.015 & -0.074 & 0.014 & 0.075 \\
\hline & & [0.029] & {$[0.030]^{* *}$} & [0.041] & {$[0.044]^{*}$} \\
\hline \multirow[t]{2}{*}{ Children } & \# of children 0-16 & -0.002 & 0.009 & -0.008 & 0.001 \\
\hline & & [0.007] & {$[0.006]$} & [0.010] & [0.011] \\
\hline \multirow[t]{3}{*}{ Migrant status } & Non-migrant & (ref) & (ref) & (ref) & (ref) \\
\hline & Return migrant & 0.065 & -0.055 & 0.156 & -0.166 \\
\hline & & [0.045] & {$[0.036]$} & {$[0.054]^{* * *}$} & {$[0.048]^{* * *}$} \\
\hline
\end{tabular}

Source: authors' elaboration based on MAFE-Senegal (2008)

Notes: $\mathrm{N}=1062$; standard errors in brackets; Statistical significance: *** at 1\%; ** at 5\%; $*$ at $10 \%$

The estimates for the control variables are in accordance with expected associations. The results indicate that there is strong persistence in the occupational status. Being in a skilled job, unskilled job, selfemployed or without income-generating work at the age of 25 or before the first departure increases considerably the probability of being in the same occupational group at the time of the survey. Women are more likely to be inactive or to perform an activity which generates no income and are less likely to be in skilled wage-employment than men. However, there is no statistically significant difference with regard to unskilled jobs and self-employment. The better educated access more easily skilled jobs and individuals without any education are the most likely to become self-employed, suggesting that the predominant type of business activity does not require high levels of (formal) human capital. Being in the mid-age range increases the probability of self-employment and lowers the probability of not earning any income. Finally, married individuals are less likely to be unskilled wage-employed than singles with the same characteristics. The household head status and the number of children do not appear to have 
any statistically significant association with the occupational status, once other characteristics are controlled for.

\section{(ii) Heterogeneous migration and return experiences}

We now turn to the discussion of results on the main variable of interest, the return migrant status, to shed some light on the correlation of heterogeneous migration experiences with occupational outcomes. Interpretation of quantitative results is supported by findings from qualitative interviews which provide indications regarding the situations lived through during migration and after the return to Dakar.

Table 4 summarizes the percentage point change in the probability of being skilled wage-employed, low-skilled wage-employed, self-employed or no income earner in the region of Dakar in 2008 associated with different return migrant characteristics with respect to no migration experience. ${ }^{12}$

Table 4: The role of return migration experience for occupational status (average marginal effects)

\begin{tabular}{|c|c|c|c|c|c|c|}
\hline Variable & Category & $\begin{array}{l}\% \text { of } \\
\text { returnees }\end{array}$ & $\begin{array}{l}\text { Skilled } \\
\text { wage } \\
\text { employed }\end{array}$ & $\begin{array}{l}\text { Low- } \\
\text { skilled } \\
\text { wage } \\
\text { employed }\end{array}$ & $\begin{array}{l}\text { Self- } \\
\text { employed }\end{array}$ & $\begin{array}{l}\text { No } \\
\text { income } \\
\text { earner }\end{array}$ \\
\hline \multirow[t]{3}{*}{ 1. Migration experience } & Non-migrant (ref) & & ref & ref & ref & ref \\
\hline & Return migrant & $100 \%$ & 0.065 & -0.055 & 0.156 & -0.166 \\
\hline & & & {$[0.045]$} & {$[0.036]$} & {$[0.054]^{* * *}$} & {$[0.048]^{* * *}$} \\
\hline \multirow[t]{5}{*}{ 2. Return motive } & Non-migrant (ref) & & ref & ref & ref & ref \\
\hline & Voluntary return & $49 \%$ & 0.162 & -0.097 & 0.111 & -0.176 \\
\hline & & & {$[0.074]^{* *}$} & {$[0.038]^{* * *}$} & {$[0.077]$} & {$[0.067]^{* * *}$} \\
\hline & Involuntary return & $51 \%$ & -0.010 & -0.024 & 0.185 & -0.151 \\
\hline & & & {$[0.046]$} & {$[0.044]$} & {$[0.072]^{* *}$} & {$[0.063]^{* *}$} \\
\hline \multirow[t]{5}{*}{ 3. Links to origin $\mathrm{HH}$} & Non-migrant (ref) & & ref & ref & ref & ref \\
\hline & Transfers & $29 \%$ & -0.009 & -0.014 & 0.283 & -0.260 \\
\hline & & & {$[0.042]$} & {$[0.067]$} & {$[0.097]^{* * *}$} & {$[0.071]^{* * *}$} \\
\hline & No transfers & $71 \%$ & 0.092 & -0.070 & 0.118 & -0.140 \\
\hline & & & {$[0.053]^{*}$} & {$[0.039]^{*}$} & {$[0.061]^{*}$} & {$[0.054]^{* *}$} \\
\hline \multirow[t]{7}{*}{ 4. Migration duration } & Non-migrant (ref) & & ref & ref & ref & ref \\
\hline & $1-2$ years & $29 \%$ & -0.001 & -0.023 & 0.188 & -0.165 \\
\hline & & & {$[0.036]$} & {$[0.055]$} & {$[0.093]^{* *}$} & {$[0.082]^{* *}$} \\
\hline & 3-7 years & $41 \%$ & 0.084 & -0.107 & 0.211 & -0.188 \\
\hline & & & {$[0.063]$} & {$[0.029]^{* * *}$} & {$[0.073]^{* * *}$} & {$[0.063]^{* * *}$} \\
\hline & 8 yrs or more & $30 \%$ & 0.090 & 0.041 & 0.005 & -0.135 \\
\hline & & & {$[0.081]$} & {$[0.077]$} & {$[0.088]$} & {$[0.075]$} \\
\hline \multirow[t]{5}{*}{ 5. Brain waste } & Non-migrant (ref) & & ref & ref & ref & ref \\
\hline & Brain waste & $20 \%$ & -0.028 & -0.110 & 0.304 & -0.166 \\
\hline & & & [0.040] & {$[0.030]^{* * *}$} & {$[0.116]^{* * *}$} & {$[0.117]$} \\
\hline & No brain waste & $80 \%$ & 0.095 & -0.050 & 0.125 & -0.169 \\
\hline & & & {$[0.051]^{*}$} & [0.039] & {$[0.057]^{* *}$} & {$[0.049]^{* * *}$} \\
\hline \multirow[t]{5}{*}{ 6. Foreign education } & Non-migrant (ref) & & ref & ref & ref & ref \\
\hline & Studied abroad & $20 \%$ & 0.102 & 0.076 & -0.016 & -0.162 \\
\hline & & & [0.062] & [0.083] & [0.092] & {$[0.087]^{*}$} \\
\hline & No study abroad & $80 \%$ & 0.050 & -0.065 & 0.183 & -0.168 \\
\hline & & & {$[0.052]$} & {$[0.036]$} & {$[0.060]^{* * *}$} & {$[0.053]^{* * *}$} \\
\hline \multirow[t]{5}{*}{ 7. Work abroad } & Non-migrant (ref) & & ref & ref & ref & ref \\
\hline & Worked mainly & $64 \%$ & 0.061 & -0.058 & 0.221 & -0.224 \\
\hline & & & [0.058] & {$[0.040]$} & {$[0.068]^{* * *}$} & {$[0.060]^{* * *}$} \\
\hline & Mainly inactive & $36 \%$ & 0.084 & -0.028 & 0.044 & -0.100 \\
\hline & & & [0.052] & [0.053] & {$[0.082]$} & {$[0.064]$} \\
\hline \multirow[t]{4}{*}{ 8. Destination region } & Non-migrant (ref) & & ref & ref & ref & ref \\
\hline & Europe/North & $34 \%$ & 0.086 & -0.028 & 0.086 & -0.144 \\
\hline & & & [0.063] & [0.038] & {$[0.077]$} & {$[0.071]^{*}$} \\
\hline & Africa/South & $66 \%$ & 0.058 & -0.059 & 0.174 & -0.173 \\
\hline
\end{tabular}




\section{Period of departure}

Period of departure

10. Period of return

\section{Non-migrant (ref)} $<=1975$

1976 to 1995

$>1995$

Non-migrant (ref) $<=1985$

1986 to 1997

$1998+$
[0.052]

ref

0.128

[0.100]

0.076

[0.064]

0.020

[0.039]

ref

$21 \%$

ref

0.038

0.057

[0.059]

0.070

[0.061]

\section{[0.040]}

ref

$-0.143$

$[0.019]^{* * *}$

$-0.065$

[0.047]

$-0.031$

[0.049]

ref

0.083

[0.092]

$-0.059$

[0.035]*

$41 \%$

$-0.075$

[0.039]*

$\begin{array}{ll}{[0.062]^{* * *}} & {[0.054]^{* * *}} \\ r e f & r e f \\ 0.105 & -0.090 \\ {[0.101]} & {[0.088]} \\ 0.151 & -0.162 \\ {[0.067]^{* *}} & {[0.061]^{* * *}} \\ 0.218 & -0.207 \\ {[0.105]^{* *}} & {[0.088]^{* *}} \\ r e f & r e f \\ -0.080 & -0.041 \\ {[0.069]} & {[0.085]} \\ 0.264 & -0.262 \\ {[0.073]^{* * *}} & {[0.058]^{* * *}} \\ 0.139 & -0.134 \\ {[0.085]} & {[0.075]^{*}}\end{array}$

Source: authors' elaboration based on MAFE-Senegal (2008)

Notes: $\mathrm{N}=1062$; except for Model 2 (Return motive) where $\mathrm{N}=1053$ )

Statistical significance: $* * *$ at $1 \%$; ** at $5 \% ; *$ at $10 \%$

\section{Migration experience}

Without further distinction of migration characteristics, one observes that migration experience does not seem to influence access to skilled wage-employment, which may be due to a lack of skill transferability from abroad to the origin labor market context. Moreover, the average returnee is less likely to be without an income generating job than a non-migrant and has a higher probability to be self-employed. This finding corresponds to results from other empirical studies in very diverse country contexts, supporting the hypothesis that returnees bring back skills and resources which can be used to set up a business activity. Nonetheless, returnees may constitute a heterogeneous group and this relationship may not be the same for all types of returnees.

\section{Return motive}

When distinguishing between returnees who decided about the return themselves and those who were forced into the return or in whose case the decision was taken by somebody $\mathrm{else}^{13}$, the quantitative estimates suggest that the association with occupational status varies considerably relative to individuals who never migrated. Involuntary returnees are less likely to be without an income generating job. While this suggests at first sight a positive correlation with labor market integration, the results show as well that the only category which seems to be available to involuntary return migrants is self-employment. Self-employment in form of "last-resort" activities in the informal sector entail little capital investment and exhibit low entry-barriers and may therefore require less "preparation".

The qualitative analyses provide support to this interpretation. Sam (37 years) wanted to migrate to Europe to improve his economic conditions, but he got ripped off by intermediaries and his journey ended in Cape Verde. He decided to return to Senegal after having been away for two years. He now works as cab driver in Dakar and comes often home empty-handed. He explains that he would rather be employed, for instance, as janitor. Although the salary is very low, it would at least guarantee him a regular income. Mustapha (39 years) also stresses how difficult it is to find a "good job" in Dakar. He spent six years in Guinea-Bissau and returned following his father's death: "In those days, nobody was around. My brothers were in Europe. It was only me who was there, so I went back". He trained as an electrician in Guinea-Bissau and would like to continue this work in Senegal. However, he cannot find employment and does not have enough money to set up his own business. Instead, he started working as a fisherman in the informal sector, a very precarious and unstable work, and is thinking about migrating again. Finally, Astou (36 years), self-employed hairdresser and mother of three children, had decided to migrate to Italy to improve her living conditions and to help her mother, but she had to return: "My husband asked me to return to Senegal, although he initially agreed that I left. But in Senegal, there are social problems ... When your wife leaves, people say: 'But why did you let your wife go alone ...?"'. The money she had earned in Italy allowed her to re-open her hair salon which she had owned before 
leaving. However, her return experience is not straightforward either: "It's not like before because some customers have found other hairdressers... I had to start over from scratch". Overall, the findings suggest that those who returned involuntarily to Senegal, as diverse as the underlying reasons may be, tend to face problems when attempting to reintegrate into the Senegalese labor market.

For the case of "voluntary returnees" the quantitative findings indicate that they benefitted from their migration experience and were able to prepare their return. They are less likely to be in a low-skilled job than non-migrants and more likely to be in skilled employment. There is no statistically significant positive association with self-employment, as one would expect if voluntary returnees were mainly target-savers planning a business investment since the start of the migration project. While those may also exist, the predominant case seems to be the one of returnees who become self-employed without having carefully planned their activity in advance. The case of Bouba (34 years) is an example for selfemployment following a voluntary return. He worked as vendor on Italian markets and returned with the aim to become rap artist. Having saved some money to prepare his return, he opened a grocer's store and hired several employees. Bouba plans to finance his first rap album with the revenues generated from the store and aims to start a business for video clip recordings in the longer-run, after having made money with the sale of his album. The different steps following his return are thus planned in advance.

\section{Links to origin household}

The quantitative results on remittance behavior do not allow for a differentiation between return migrant types with regard to their occupational status. Keeping links to the family by means of transferring money does not improve the chances on the labor market compared to the non-remitters.

The qualitative analysis suggests that returnees who had been remitting may take up self-employed work out of the necessity to provide continuous support to the family. The case of Babacar's (29 years) migration experience illustrates this idea. Babacar spent one year in Spain, but was expelled to Dakar. He explains his role as the supporter for his family: "The money I earned there, it was for the family, to feed them. I sent them 200,000 CFA per month". After his return and without having made additional savings, he was obliged to work again as artisanal fisherman. "A fisherman, he gains nothing. It is not even a job (...). I'd like to have a real job. The sea it is not good now (...). I'd like to leave again because I have to help my parents". While he is not able to earn as much money as during his migration, he still needs to provide continuous support to his family. Working as a fisherman is the only option he has.

\section{Migration duration}

The estimates from Model 4 highlight that individuals who stayed abroad for short to medium length durations are more likely to be self-employed and less likely to be without income generating work than non-migrants. This result may point to the two types of returnees - those who return after a very short period and enter the informal market as own account workers and those who may have acquired some transferrable financial or human capital abroad. Return migrants with medium-length migration spells seem also less likely to be in unskilled employment than non-migrants. Migrants with rather long migration spells may have had a too long interruption in their Senegalese labor market experience to benefit from their migration. Their occupational status does not differ from the situation of non-migrants. The results with regard to migration duration should however be treated with caution, as decisions regarding occupation and migration duration may be taken simultaneously.

The analysis of the qualitative interviews illustrates the role of migration duration and places the discussion in the context of other migration characteristics. Return migrants with very short migration experiences tend to regret their early return and intend to leave again, especially if they migrated with a specific goal and failed to reach it. Yézidou (30 years), for example, explains his reason to migrate to Spain: "I have my family, I have two children and a wife, life is hard, so I decided to leave. But since I came back, the situation hasn't changed". In fact, he was expelled and could not achieve his goal: "Me, I wanted to leave, to have at least a little cash to invest. I wanted to get money and to come back. Even today, I want to go there (...) to work". Longer stays could provide him with an opportunity to improve his status from the current position as traditional fisherman: "What I want is to buy a house, to build, to put my family in the house, to buy a boat and to become a fishmonger". This unattained goal fuels his 
wish to migrate again. Mountaga (34 years), dressmaker, spent only one year in Guinea-Bissau. He wanted to work and improve his living conditions, but found that the situation in Guinea-Bissau was even more difficult than back in Senegal: "I wanted more money, succeed with my life. I thought it would get better, but in Senegal it is better than there (...). I came back because I haven't achieved what I wanted. People there are looking for something to eat instead of going to get a boubou ${ }^{14}$ made". At present, his situation is difficult. Without a sewing machine and a workshop, he has to borrow a friend's sewing machine when he has customers.

A very long absence from Senegal can also have negative impacts on reintegrating into the labor market. Bara (50 years), a chef who spent 26 years abroad (in Cote d'Ivoire, Gabon, Burkina Faso and Mali) explains the following about his return: "I don't regret having returned. What I regret is not having returned earlier. I regretted this even more...when I saw my schoolmates, who had worked with me in 1990 in the largest hotel in Senegal. During my absence, friends have climbed the ladder to the point that one of them even became the director of the hotel. He had learned catering like me. They had the patience to stay. And when I returned, they were more successful than me..."

\section{Brain waste}

The following return status definition examines the role of working in a job below the level of qualification while abroad, a situation of "brain waste". Returnees with such experiences are, according to the quantitative estimates, less likely to be in unskilled wage-employment. An explanation may be that, given their educational level, they are not willing to accept once again a job below their level of qualification after their return to Senegal. At the same time, return migrants who have not gained any or even lost human capital are more likely to be self-employed than non-migrants, indicating that the average business activity can be performed without further gains in human capital. Returnees who experienced brain waste may start a low-scale business activity as they are not able to access wage positions corresponding to their formal level of education, given the strong competition for salaried jobs. However, also individuals who worked abroad at a level corresponding or even exceeding their qualification are more likely to start businesses than non-migrants, if they do not enter skilled wage jobs, the other category in which they are overrepresented. While we are not able to test the hypothesis, the findings suggest that there are two types of return entrepreneurs.

Qualitative findings indicate that migration experience can still play a positive role for labor market status after return, even if the migrant worked below the level of qualification. Khar (42 years) graduated in Law from the University of Dakar, but when she was in Italy she worked on the assembly line for more than five years. She benefited from a type of human capital that is not taken into account by the variable "brain waste" which focuses exclusively on occupational status: the acquisition of the Italian language. Upon her return to Senegal she was employed as executive assistant by Italian investors.

\section{Foreign education}

Foreign education does not seem to be easily transferrable to Senegal, as the multinomial logit estimates show that those who acquired formal education abroad have no better chances of finding a skilled job than non-migrants. Returning students do thus not appear to contribute to significant "brain gain". The qualitative analysis illustrates the case of individuals who have studied abroad and face difficulties in finding a job that corresponds to their qualifications after having returned to Dakar. Saliou (23 years) studied for two years engineering in Morocco before returning to Senegal because he was homesick. Ever since his return, he has been actively searching for a job: "I came back from Morocco more than one year ago, and since my return I have been looking for a job but I haven't found one yet (...). It is difficult, especially in my field of work. There are not many positions in the field. And more and more people are looking for work. There are many among us fighting for the same jobs". He decided to continue his training as an engineer, while still searching for jobs in parallel. Bashir's (39 years) experience demonstrates that the professional reinsertion may take a long time. Bashir left Senegal after completing a Masters degree at the University of Dakar to continue his studies in France, where he lived for more than six years. He studied development, demography and computer science. Due to money problems, he decided to return. It took him four years to find a job: "I could not find employment. I did 
several internships with companies at the harbour, stocking goods. It was to stay active, to find something, but it paid poorly... It had nothing to do with my qualifications". Finally he was employed on the basis of his Senegalese Master degree. "It's as if I had not evolved between before and after six years in France. It's as if I had not evolved". Bashir's case shows that foreign academic qualifications do not imply an automatic professional advancement.

\section{Work experience gained abroad}

In the following model we distinguish return migrants by the main labor force status while abroad. Those who spent most of their time abroad working are more likely to start a business and have a lower probability than non-migrants to be a "no income earner" at the time of the survey. Foreign work experience may therefore be more important than studies in explaining self-employment after return.

However, once again, a distinction has to be made between "entrepreneurs", who planned to start a business and have accumulated enough capital to carry out their plans, and those who ultimately become self-employed and run a small business activity by themselves, predominantly in the informal sector. The latter situation has already been illustrated with qualitative results for patterns about involuntary return, transfers to support family members at origin and the "brain waste" cases. Let us return to the situation of those who, thanks to the accumulated capital during migration, have established a business in the formal sector. This is the case of Kouna (49 years). He lived for 33 years outside of Senegal and most of that time he spent in Italy. There, he worked as a cook and a trader: "I really enjoyed the work in the kitchen. I also learned trade there. I used to trade African art, fabrics, djembe ${ }^{15}$... I came here, and I bought. I was doing fairs, restaurants (...). When I went abroad, I intended to improve my life. I did not intend to stay". He bought land in Dakar and, indeed, he returned to Senegal where he used his experience gained in Italy to start his own restaurant. Today he sells 200 meals a day. Pape (54 years) also set his mind on returning to perform an activity in connection with the one he had done for years in France: "Once you acquired that technical knowledge, you want to come back and prove that you succeeded. [...] I told myself that I had the training, I had the money, I had the brains. I thought I had a big brain and that I could get something here. I was technologically advanced in comparison to Senegal". Having worked in the print business abroad, he invested in a business for printing materials. These returnees perceive their reinsertion experience as successful and want to stay in Senegal. They returned voluntarily after a sufficient time abroad and have managed to start a business activity thanks to the capital accumulated abroad.

\section{Destination region and period of departure}

According to the quantitative findings, coming back from Europe or another country in the North does not seem to facilitate attachment to a specific occupational status when compared to individuals who never lived outside of Senegal. The work experience gained in the North may be less easily transferable to the labor market context in Dakar. In accordance with our hypothesis, returnees who had migrated to another African country have a higher probability to start a business activity than non-migrants. Since it is rather unlikely that large amounts of capital are accumulated during stays in another African county, the self-employed activities are again likely to be rather small-scale activities. In the qualitative analyses, one cannot detect any pattern by migration destination. The quantitative estimates by period of departure show an increased tendency towards self-employment among returnees over time, a result which is also reflected in the following variable: the period of return.

\section{Period of return}

The last model includes an indicator for the period of return, a variable which reflects the social, political and economic context at the time of return. ${ }^{16}$ Returnees who came back between the mid 1980s and the mid 1990s, a period characterized by economic difficulties, are more likely to be self-employed than individuals who never migrated and less likely to be low-skilled wage employed or no income earners. During this period it may have been easier to access self-employment than wage employment, once the labor market experience was interrupted by a migration episode. More recent returnees do not seem to differ from non-migrants with regard to their occupational status. As most respondents to the qualitative interviews returned during the past ten years, the life stories do in general not address the longer-term 
role of changing economic and political context. While interviewees emphasize that the current economic situation is more difficult than before, these limitations may affect non-migrants equally. As Pape (54 years), who migrated in the 1970s and returned ten years ago, explains: "In the years 1975 to 1980, our desire was to go and get a good training and then return home. At that time, the crisis in Africa was not so evident. At this time, when we had a feeling for business, it was very easy. Today it's different... Reality is different..."

\section{CONCLUSION}

At first sight, the quantitative evidence on the occupational status of non-migrants and return migrants in 2008 seems to confirm the evidence from previous literature with regard to the role played by return migrants in self-employment. In an optimistic interpretation, this would suggest a gain from migration, which can be exploited after return in the form of a "productive" entrepreneurial activity. At the same time, return migrants seem to be less likely to be without an income generating work than non-migrants. This is an indication that they are generally able to join the labor market after their return and that the average return migrant does not enter the category of "retirement returnees". However, the introduction of migration and return experiences, the consideration of the notion of a duality in the informal market and the combination of the quantitative with the qualitative evidence, leads us to qualify this result.

On the one hand, a higher probability of self-employment compared to non-migrants can be observed for individuals who came back involuntarily, who had migrated to a country in Africa and who returned during the 1980s and 1990s (a period in which the economic context in Senegal was difficult), for those who experienced brain waste and for individuals with short migration durations. In these cases, migration is unlikely to have contributed to significant capital mobilization and/or the return lacks preparation. Rather than a choice, the self-employment status appears as a "last resort" for individuals who are not able to access wage-employment, but are obliged to continuously sustain the needs of their families, an interpretation which is also supported by the qualitative interviews.

On the other hand, the positive role played by foreign work experience in general and work at or above the returnee's qualification level in particular, as well as the "medium-length" stays abroad suggest that the 'know-how' accumulated through the stay abroad may be useful in an entrepreneurial activity once back in Senegal. It possibly allows for a higher-value and more sustainable activity. In this case, the self-employment activity may be a premeditated choice of the returnee, representing the aim of the migration experience. The finding that individuals who experienced only one migration episode and one return have a higher probability of becoming self-employed also supports this view. However, as the qualitative interviews show, the quality of the job performed abroad matter for the success of the activity started after return.

The fact that returnees are in general less likely to be in unskilled wage employment than non-migrants indicates that self-employment may represent a substitute for unskilled wage-employment for otherwise similar individuals. At the same time, we find specific types of returnees who access more easily skilled wage jobs: voluntary returnees and individuals who worked abroad at or above their level of qualification. Foreign education, on the other hand, does not facilitate obtaining a skilled job. Human capital accumulation through learning-by-doing may therefore matter more than formal education.

With respect to the role of return migrants in business creation, the findings from both approaches indicate thus that self-employed returnees do not form a homogenous group. Instead, it appears necessary to distinguish between two types of self-employed return migrants, which reflect at the same time the duality in the informal labor market. The qualitative analysis also captures the quality of the work through the subjective measure of work satisfaction, an element which is difficult to integrate in the quantitative analysis. As illustrated in Table 5, one finds on the one hand returnees who are successful and satisfied in their entrepreneurial activity, but one also finds a group of unsuccessful and unsatisfied self-employed and differences between these two groups can be associated with differential features of the migration and return experiences. ${ }^{17}$ 
Table 5: Satisfied/successful self-employed returnees vs. Unsatisfied/unsuccessful self-employed returnees

\begin{tabular}{|c|c|c|}
\hline & $\begin{array}{l}\text { "Satisfied" and } \\
\text { successful self-employed }\end{array}$ & $\begin{array}{l}\text { "Unsatisfied" and } \\
\text { unsuccessful self-employed }\end{array}$ \\
\hline Return motive & Voluntary & Involuntary \\
\hline Return preparation & Present & Absent \\
\hline Wants to re-migrate & No (or only short stays abroad) & (Probably) yes \\
\hline $\begin{array}{l}\text { Meaning and aim of the } \\
\text { professional activity }\end{array}$ & $\begin{array}{l}\text { Realization of an objective, } \\
\text { successful conclusion of the } \\
\text { migration project (acquired } \\
\text { financial and human capital in } \\
\text { view of a future activity). Self- } \\
\text { employment generates relatively } \\
\text { high revenues. }\end{array}$ & $\begin{array}{l}\text { Obligation, otherwise there would } \\
\text { be no resources to sustain the } \\
\text { family. Represents a temporary } \\
\text { solution while searching for an } \\
\text { unqualified wage-employment. } \\
\text { Self-employment activity } \\
\text { generates low revenues. }\end{array}$ \\
\hline $\begin{array}{l}\text { How the return migrant feels } \\
\text { about himself }\end{array}$ & Proud of himself & Ashamed of himself \\
\hline Transfers during the migration & $\begin{array}{l}\text { No, not necessarily (if yes, also } \\
\text { representing social links, not } \\
\text { purely financial ones) }\end{array}$ & Yes, needed to sustain the family \\
\hline Migration duration & Optimal & Too short \\
\hline $\begin{array}{l}\text { Accumulated knowledge, know- } \\
\text { how abroad }\end{array}$ & $\begin{array}{l}\text { Yes, useful for the activity after } \\
\text { the return. Through work } \\
\text { experience rather than studies } \\
\text { abroad. }\end{array}$ & $\begin{array}{l}\text { No, and in any case not useful for } \\
\text { the type of activity taken up after } \\
\text { return. }\end{array}$ \\
\hline Worked abroad & Yes & Yes, but in unqualified occupation \\
\hline Migrant's Destination & No clear impact & No clear impact \\
\hline Short returns (visits) & Yes & No \\
\hline
\end{tabular}

Public policy commonly expects return migrants to contribute to "development" after their return through entrepreneurial activities, knowledge and skills acquired abroad and brought back, or to - in the "worst case" - reintegrate smoothly in to the local labor market at a similar level to the one of nonmigrants. Moreover, policies rarely focus on the differential reintegration process depending on the motive of return - "voluntary" or "involuntary". The findings of this analysis suggest that involuntary returns tend to be followed by unsuccessful reintegration processes and the intention to re-migrate. Any forced return is thus unlikely to be beneficial. Moreover, the reinsertion process is strongly linked to the labor market context in Senegal. To prevent returnees from being pushed in a low-level independent activity, policies may aim at supporting the return process more actively, in particular if the migration experience was "unsuccessful". A better integration at destination, on the other hand, would be a condition for more positive migration experiences, including the accumulation of useful work experience as well as social and financial capital.

\section{References}

ANSD (2009). Situation économique et sociale du Sénégal en 2008. Technical report, Agence Nationale de la Statistique et de la Démographie, Dakar.

ANSD (2010). Situation économique et sociale du Sénégal en 2009. Technical report, Agence Nationale de la Statistique et de la Démographie, Dakar.

Ammassari, S. \& Black, R. (2001). Harnessing the Potential of Migration and Return to Promote Development. IOM Migration Research Series 5, International Migration Organization.

Ammassari, S. (2004). From Nation-Building to Entrepreneurship: The Impact of Elite Return Migrants in Cote d'Ivoire and Ghana. Population, Space and Place 10(2), 133-154.

Ammassari, S. (2005). L'effet du retour des travailleurs migrants sur le développement. Coopération Sud, PNUD, New York, 91-115. 
Arif, G. M. \& Irfan, M. (1997). Return Migration and Occupational Change: The Case of Pakistani Migrants Returned from the Middle East. The Pakistan Development Review 36(1), 1-37.

Barrett, A. \& O'Connell, P.J. (2001). Is There a Wage Premium for Returning Irish Migrants? Economic and Social Review 32(1), 1-21.

Beauchemin, C. \& Kabbanji, L. (2010). MAFE survey guidelines. Retrieved from: http://mafeproject.site.ined.fr/en/methodo/.

Black, R. \& Castaldo, A. (2009). Return Migration and Entrepreneurship in Ghana and Côte d'Ivoire: The Role of Capital Transfers. Tijdschrift voor Economische en Sociale Geografie 100(1), 44-58.

Black, R., King, R. \& Tiemoko, R. (2003). Migration, Return and Small Enterprise Development in Ghana: A Route out of Poverty? (Sussex Migration Working Paper 9). Retrieved from: www.sussex.ac.uk/migration/documents/mwp9.pdf

Borodak, D. \& Piracha, M. (2011). Occupational choice of return migrants in Moldova. Eastern European Economics 49(4), 24-46.

Carling, J. (2004). Emigration, Return and Development in Cape Verde: The impact of closing Borders. Population, Space and Place 10(2), 113-132.

Cassarino, J. (2004). Theorising Return Migration: the Conceptual Approach to Return Migrants Revisited. International Journal on Multicultural Societies 6(2), 253-279.

Cassarino J-P. (2008). The Conditions of Modern Return Migrants - Editorial Introduction, International Journal on Multicultural Societies 10(2), 95-105.

Chappart, P. (2008, October). Expériences de retour forcé au Cameroun : récits de franchissement de frontières. Paper presented at the Journées d'étude de l'EHESS "Migrations : nouvelles pratiques, approches plurielles", Paris.

Cheng, S. \& Long, J.S. (2007). Testing for IIA in the Multinomial Logit Model. Sociological Methods \& Research 35(4), 583-600.

Co, C.Y., Gang, I.N. \& Myeong-Su, Y. (2000). Returns to Returning. Journal of Population Economics 13(1), 57-79.

Colton, N.A. (1993). Homeward bound: Yemeni return migration. International Migration Review 27(4), 870-882.

De Vreyer, P., F. Gubert, \& A. Robilliard (2010). Are there returns to migration experience? An empirical analysis using data on return migrants and non-migrants in West Africa. Annales d'Economie et de Statistique 97/98, 307-328.

Démurger, S., \& Xu, H. Return Migrants (2011): The Rise of New Entrepreneurs in Rural China, World Development 39(10), 1847-1861.

Diatta, M. A. \& Mbow, N. (1999). Releasing the development potential of return migration: The case of Senegal. International Migration 37(1), 243-264.

DPS (2004). L'emploi, le chômage et les conditions d'activité dans l'agglomération de Dakar. Résultats de la phase 1 de l'enquête 1-2-3 de 2002. Technical report, Direction de la prévision et statistique, Ministère de l'économie et des finances, Dakar.

Dustmann, C. \& Kirchkamp, O. (2002). The Optimal Migration Duration and Activity Choice after ReMigration. Journal of Development Economics 67, 351-372.

Dustmann, C. (2000). Temporary Migration and Economic Assimilation (IZA Discussion Paper 186). Retrieved from: http://ftp.iza.org/dp186.pdf 
Flahaux, M.-L. (2009). Les migrations de retour et la réinsertion des Sénégalais dans leur pays d'origine. Master dissertation, Université catholique de Louvain. Retriever from: http://www.ined.fr/fichier/t_telechargement/34510/telechargement_fichier_fr_m.moire.flahaux.pdf

Flahaux, M-L., Beauchemin, C., Schoumaker B. (2010). Partir, revenir: tendances et facteurs des migrations africaines intra- et extra-continentales (MAFE Working Paper 7). Retrieved from: http://www.ined.fr/fichier/t_telechargement/41828/telechargement_fichier_fr_wp7_flahaux_etal_2010 .pdf

Flahaux, M-L., Kabbanji, L. (2010, September). Return migration to Senegal: Do policies meet migrants' needs? Paper presented at the European Population Conference, Vienna.

Gmelch, G. (1980). Return Migration. Annual Review of Anthropology 9, 135-159.

Guilmoto, C. (1998). Institutions and migrations. Short-term versus long-term moves in rural West Africa. Population Studies 52(1), 85-103.

Gubert, F. \& Nordman, C. J. (2008). Who Benefits Most from Migration? An Empirical Analysis Using Data on Return Migrants in the Maghreb (MIREM-AR; 2008/03), Robert Schuman Centre for Advanced Studies. Retrieved from: http://hdl.handle.net/1814/8888

Gubert, F., \& Nordman, C. J. (2011). Return migration and small enterprise development in the Maghreb. In S. Plaza, \& D. Ratha (Eds.), Diaspora for development in Africa (pp. 103-126). Washington: The World Bank.

Harris, J. \& Todaro, M.P. (1970). Migration, Unemployment and Development: A Two-Sector Analysis. American Economic Review 60, 126-142.

Ilahi, N. (1999). Return Migration and Occupational Choice. Review of Development Economics 3(2), 170-186.

Kilic, T., Carletto, G., Davis, B. \& Zezza, A. (2007). Investing Back Home: Return Migration and Business Ownership in Albania (World Bank Policy Research Working Paper 4366). Retrieved from: http://www-

wds.worldbank.org/external/default/WDSContentServer/IW3P/IB/2007/09/24/000158349_200709241 01806/Rendered/PDF/WPS4366.pdf.

Kropko, J. (2010). A Comparison of Three Discrete Choice Estimators. Unpublished. Retrieved from: http://www.unc.edu/ kropko/paper1.pdf.

Lindstrom, D. P. (1996). Economic Opportunity in Mexico and Return Migration from the United States. Demography 33(3), 357-374.

Massey, D. S. \& Parrado, E. A. (1998). International Migration and Business Formation in Mexico. Social Science Quarterly 79(1), 1-20.

McCormick, B. \& Wahba, J. (2001). Overseas Work Experience, Savings and Entrepreneurship amongst Return Migrants to LDCs. Scottish Journal of Political Economy 48(2), 164-178.

Mesnard, A. (2004). Temporary Migration and Capital Market Imperfections. Oxford Economic Papers 56(2), 242-262.

Ministère de l'Economie et des Finances, République du Sénégal (2004a). Situation économique et sociale du Sénégal.

Ministère de l'Economie et des Finances, République du Sénégal (2004b). Rapport de synthèse de la deuxième enquête sénégalaise auprès des ménages (ESAM II).

Muschkin, C. G. (1993). Consequences of Return Migrant Status for Employment in Puerto Rico. International Migration Review 27(1), 79-102. 
Nair, P. G. (1999). Return of Overseas Contract Workers and their Rehabilitation and Development in Kerala (India) - A Critical Account of Policies, Performance and Prospects. International Migration 37(1), 209-242.

Ndione, B. \& Broekhuis, A. (2006). Migration international et développement. Points de vue et initiatives au Sénégal (Working Papers Migration and Development Series Report 8), Radbout University, Nijmegen.

Nicholson, B. (2004). Migrants as Agents of Development: Albanian Return Migrants and MicroEnterprise. In D. Pop (ed.). New Patterns of Labor Migration in Central and Eastern Europe (pp. 94110). Cluj Napoca: Public Policy Centre.

Piracha, M. \& Vadean, F. (2010). Return Migration and Occupational Choice: Evidence from Albania. World Development 38(8), 1141-1155.

Robin, N., Lalou, R., Ndiaye, M. (2000). Facteurs d'attraction et de répulsion à l'origine des flux migratoires internationaux. Rapport National Sénégal Push-Pull. European Commission, Eurostat.

Sinatti, G. (2011). 'Mobile Transmigrants' or 'Unsettled Returnees'? Myth of Return and Permanent Resettlement among Senegalese Migrants. Population, Space and Place 17(2), 153-166.

Sjaastad, L.A., (1962). The Costs and Returns of Human Migration. Journal of Political Economy 70(5), 80-93.

Stark, O. (1991). The Migration of Labor. Oxford: Blackwell.

Stark, O., Helmenstein, C. \& Yegorov, Y. (1997). Migrants' Savings, Purchasing Power Parity, and the Optimal Duration of Migration. International Tax and Public Finance 4, 307-324.

Tall, S. (2002). L'émigration internationale sénégalaise d'hier à demain. In M. C. Diop (Ed.), La Société sénégalaise entre le local et le global (pp. 549-578). Paris: Karthala.

Tall, S. M. (2009). Investir dans la ville africaine. Les émigrés et l'habitat à Dakar. Dakar-Paris: CREPOS -Karthala.

Tani, M. \& Mahuteau, S. (2008). Return Migration and Working Choices (MIREM-AR; 2008/01), Robert Schuman Centre for Advanced Studies. Retrieved from: http://cadmus.eui.eu/bitstream/handle/1814/8221/MIREM_AR_2008_01.pdf?sequence=1

Thomas-Hope, E. (1999). Return Migration to Jamaica and its Development Potential, International Migration 37(1), 183-207.

Traore, S. (1994). Les modèles migratoires soninké et poular de la Vallée du Fleuve Sénégal. Revue européenne des migrations internationales 10(3), 61-81.

Wahba, J. \& Zenou, Y. (2009). Out of Sight, Out of Mind: Migration, Entrepreneurship, and Social Capital (CEPR Discussion Paper Series 7552). Retrieved from: http://www.cepr.org/pubs/dps/DP7552.asp

Woodruff, C. M. \& Zenteno, R. (2001). Remittances and Microenterprises in Mexico (Graduate School of International Relations and Pacific Studies Working Paper). Retrieved from: http://papers.ssrn.com/sol3/papers.cfm?abstract_id=282019

World Bank (2007). Senegal Looking for Work - The Road to Prosperity. Country Economic Memorandum (Report No. 40344-SN).

Yang, D. (2006). Why do Migrants Return to Poor Countries? Evidence from Philippine Migrants' Responses to Exchange Rate Shocks. The Review of Economics and Statistics 88(4), 715-735.

\section{Notes}


${ }^{1}$ Results presented in this paper have been obtained using the MAFE-Senegal survey, coordinated by INED (C. Beauchemin), in association with the Université Cheikh Anta Diop (P. Sakho). The project also involves the Pompeu Fabra University (P. Baizan), the Consejo Superior de Investigaciones Científicas (A. Gonzalez-Ferrer), and FIERI (Forum Internazionale ed Europeo di Ricerche sull'Immigrazione; E. Castagnone). The survey was conducted with the financial support of INED, the Agence Nationale de la Recherche, the Ile de France Region, the FSP programme entitled 'International Migrations, territorial reorganizations and development of the countries of the South'. Data were collected in Senegal as well as in France, Spain and Italy. This study uses only the data collected in Senegal.

${ }^{2}$ See, for example, the review by Cassarino (2004).

${ }^{3}$ See for quantitative studies e.g. Piracha and Vadean (2010), Démurger and Xu (2011), Ilahi (1999), Arif and Irfan (1997), McCormick and Wahba (2001), Dustmann and Kirchkamp (2002), Wahba and Zhenou (2009), Woodruff and Centeno (2002), Mesnard (2004), Nair (1999), De Vreyer et al (2010), Massey and Parrado (1998), Kilic et al. (2007), Tani and Mahuteau (2008), Gubert and Nordman (2011), Gubert and Nordman (2008), Muschkin (1993), Black and Castaldo (2009) and Lindstrom (1996). Authors who have explored the issue in a more qualitative way include, for instance, Ammassari and Black (2001), Black et al. (2003), Ammassari (2004), Nicholson (2004), Thomas-Hope (1999) and Sinatti (2011).

${ }^{4}$ If migrants decide on duration depending on the type of work they plan to take up after return, length of stay abroad would be endogenous (Dustmann and Kirchkamp, 2002). One would, however, have to assume that individuals can optimize the migration duration, implying that migrants can choose the optimal timing for return. Given that not all returns are "voluntary" in the Senegalese case; this may hence apply only to a subset of return migrants.

${ }^{5}$ As one reviewer suggested, characteristics of migration flows in terms of skills may also have changed over time, influencing the occupational outcomes. Cross-tabulations from the MAFE-survey suggest that returnees who migrated longer time ago (before 1975) were more likely to have tertiary education than those who had left more recently.

${ }^{6} 43$ interviews were conducted in French and transcribed in French and 3 interviews were conducted in Wolof and directly transcribed in French. The translations into English (cross-checked by both authors) aim to convey as closely as possible the message but also the phrasing in terms of word choice, complexity of sentence structure, logical breaks in the thought process, hesitations etc. Therefore, some "mistakes" in the citations were purposely introduced in the English translations. Names of interviewees have been anonymized.

${ }^{7}$ A detailed description of the MAFE sampling design can be found in the document Beauchemin, C. \& Kabbanji, L. (2010)

"MAFE survey guidelines"; http://mafeproject.site.ined.fr/en/methodo/. Sampling weights have been applied in the descriptive as well as the multivariate analysis to account for the sampling design.

${ }^{8}$ The assumption of Independence of Irrelevant Alternatives (IIA) is tested with both Hausman and Small-Hsiao LikelihoodRatio tests. When performing the tests after estimating the multinomial logit without taking account of the sampling design, none of the tests rejects the null hypothesis. Hausman tests cannot be implemented after estimation with sampling weights. 
The Small-Hsiao test as only possible test rejects now the IIA assumption, a result which cannot be easily explained. Given these contradictory results we consulted in more depth the recent literature on standard IIA tests as well as the effect of a violation of the assumption. Cheng and Long (2007) examine tests using Monte Carlo simulations and conclude that "tests are not useful in assessing IIA", as size properties are dependent on the data structure of explanatory variables and may be severely inflated. The authors recommend taking care to define outcomes that are no substitutes. Kropko (2010) simulates the effect of varying levels of violations of IIA on coefficient estimates and concludes that bias is limited even in case of relatively severe violation. Alternative estimation methods such as nested logit (with degenerate branch for no income earners) and multinomial probit are not identified in this application, as we do not include alternative-specific variables. Given that the occupational status categories represent reasonably distinct categories, we present the multinomial logit estimates.

${ }^{9}$ If unobservable characteristics affect early occupational status as well as current one, this variable may be endogenous and coefficient estimates biased. At the same time, omitting this variable would also induce bias. Given the descriptive character of the quantitative analysis, we report the estimate results with demanded caution.

${ }^{10}$ Performing an exogeneity test in the case of a multinomial outcome model is not straightforward. In exploratory analyses, we followed Piracha and Vadean (2010) and tested for exogeneity of the binary return migrant indicator by including the generalized probit residual from a first stage equation on migrant status as additional variable in the MNL. Similarly to several previous papers, we reverted to information about migrant networks to construct exclusion restrictions. Firstly, we used a dummy variable measuring whether members of the extended family or friends were living in another African country when the respondent was 23 years old. This age corresponds to the median age of first departure in the sample. If the departure happened at or before age 23, we used the network previous to departure. As second exclusion restriction we used the proportion of migrant households in the department of birth, constructed from the census 2002 data. While the specification performs reasonably well (significant in the selection equation: $F(2,1051)=5.94$, p-value: 0.002 ; insignificant in the $\mathrm{MNL}$ : $\mathrm{F}(6$, 1056) $=0.95$, p-value: 0.458 ) and the included residuals are statistically insignificant $F(3,1049)=0.34$, p-value: 0.795$)$, we are not sufficiently convinced of (i) the quality of the exclusion restrictions and (ii) the appropriateness of including generalized probit residuals in the multinomial logit estimation. We prefer therefore to refrain from causal interpretations.

${ }^{11}$ Marginal effects are presented as other formats, such as coefficients or odds ratios in the multinomial logit model are more difficult to interpret. The estimates should not be interpreted as causal effects, as the term suggests, but as associations.

${ }^{12}$ We also considered other variables suggested by the theoretical and empirical literature, in particular whether the returnee had made visits to the origin country while abroad, membership in migrant associations and whether the return was intended to be permanent or temporary. Due to small cell sizes for certain categories, these variables could not be examined.

\footnotetext{
${ }^{13}$ The variable return motive is coded based on answers to an open question in the survey.

14 "Boubou" is a type of clothing worn in West Africa.

15 "Djembe" are African hand drums.
} 
${ }^{16}$ Since the analysis reflects the occupational status in 2008 , the period of return is also linked to the time since return. The discussion of the results assumes a certain persistency in the occupational status, with individuals remaining largely in the sector they entered when they returned. The result on the variable "early occupation status", which dates back even longer, provides a certain support to this assumption.

${ }^{17}$ This table brings together conclusions from the qualitative and the quantitative analysis. Not all points are covered by both approaches. 